\title{
CROWDFUNDING AS AN EMERGING FUNDRAISING TOOL: WITH SPECIAL REFERENCE TO THE MALAYSIAN REGULATORY FRAMEWORK
}

\author{
Apnizan Abdullah *
}

\begin{abstract}
The booming of the crowdfunding industry all over the globe has prompted many countries to amend their laws and regulations. Many brilliant ideas and projects, be it business ventures or social causes, have been successfully funded via crowdfunding. The technological advancement through the Internet has made crowdfunding viable as a supplementary method to traditional fundraising mechanisms. This paper discusses the development of crowdfunding worldwide, including Islamic crowdfunding and the regulatory regimes implemented in various jurisdictions. A special reference is made to the Malaysian regulatory framework since Malaysia is one of the countries that recognises the emergence of crowdfunding as a fundraising vehicle. The paper makes various recommendations to government regulators to tackle some loopholes in the existing legal framework in Malaysia.

Key words: crowdfunding, equity crowdfunding, Islamic crowdfunding, community based crowdfunding, legal framework, charity.
\end{abstract}

\section{Introduction}

Crowdfunding has recently gained world attention as an alternative financing mechanism to the traditional fundraising methods for business ventures or social projects. Internet-mediated crowdfunding, in particular, is an emerging technique used to solicit funds from other persons to finance various projects. The emergence of crowdfunding platforms since the early the 2000's until the present, such as GlobalGiving, ArtistShare, Prosper.com, Kiva.org, Lending Club, SliceThePie, IndieGoGo, Spot.us, KickStarter, GoFundMe, Funding Circle and RocketHub, has proved the wisdom behind crowdfunding as an effective platform in actualising ideas or projects, be it business ventures or social causes.

Fundamentally, crowdfunding is not new. The classical success story of crowdfunding could be traced to the construction of the pedestal of the Statue of Liberty. The Statue of Liberty was shipped from France as a diplomatic gift from the French government to the US. Very unfortunately, the US government was unable to raise the funding of $\$ 250,000$ for a granite plinth for the statue. Although the American Committee of the Statue of Liberty was appointed as 
the special task force to raise the funds, more than a third of the amount needed was still short. The shortfall in the funds prompted a renowned publisher, Joseph Pulitzer, to launch a fundraising campaign in his newspaper, The New York World. Eventually, the statue stood as a proof of the power of crowdfunding through public donations. ${ }^{1}$ Another proof was the success of the British rock band Marillion in 1997 collecting US\$60,000 from their fans via Internet calls to finance their concert. ${ }^{2}$ The list of the proofs has been increasing from year to year at its trajectory phase.

As of 2014 , the crowdfunding industry worldwide has reached $\$ 16.2$ billion. ${ }^{3}$ Essentially, crowdfunding has grown based on two major categories $v i z$ : community based crowdfunding and financial return crowdfunding. The first category could be further divided into two, namely, donation based and reward based crowdfunding, while the latter can either be peer-to-peer (P2P) lending or equity crowdfunding. The rising of crowdfunding platforms riding on those categories such as GlobalGiving, GoFundMe and DonorsChoose for donation based, ArtistShare, SliceThePie, IndieGoGo and KickStarter for reward based, Prosper.com, Kiva.org, Lending Club and Funding Circle for P2P lending and Micro Ventures and CircleUp for equity crowdfunding has indeed signalled the worldwide potential of crowdfunding. Prior research revealed that crowdfunding has funded a myriad of social and economic efforts, such as social and charitable projects, NGOs projects, business start-ups for SMEs, music and films industries and scientific research undertakings. ${ }^{4}$ Due to its exponential growth worldwide, crowdfunding is seen as a potential fundraising method which could supplement traditional methods of fundraising such as soliciting venture capital ${ }^{5}$, bank loans, angel capital ${ }^{6}$, state promotion and others. ${ }^{7}$

Recognising its promising growth, many countries, such as the US, the UK, China, Australia, Singapore and others, have taken steps to provide necessary adjustments to their regulatory regimes to accommodate the operation of crowdfunding. Malaysia is no exception. However, the current phase of the efforts is focused mainly on financial return crowdfunding, which governs either P2P lending activities or equity crowdfunding exercise, or both. Laws and regulations for the community-based crowdfunding, particularly donation based crowdfunding in many jurisdictions including Malaysia, are still unclear. California is a proactive state in regulating donation-based crowdfunding under the purview of commercial fundraiser regulation ${ }^{8}$ to cater for this fast growing industry. ${ }^{9}$ Thus, this paper delineates the development of crowdfunding worldwide and its regulatory regimes, with special reference to the Malaysia regulatory framework. Eventually, the paper highlights the loopholes in the current Malaysian regulatory framework and recommends suitable regulatory adjustments to accommodate the fast growing crowdfunding industry. 


\section{Background of the Study}

\subsection{Crowdfunding: An Emerging Fundraising Device}

Obtaining financial assistance at the initial stage of a small/micro-business venture or other project is a common problem faced by entrepreneurs despite their excellent business ideas or projects..$^{10}$ The problem becomes worse when they are not able to provide collateral for financial assistance and face difficulties in attracting investors due to insufficient cash flow of the business start-up and the presence of significant information asymmetry with investors. When seeking financing from any financial intermediary or equity venture company, credit screening is another hurdle that can impede their ability to obtain it. ${ }^{11}$ Traditional sources of capital, such as bank loans, venture and angel capital, are relatively difficult to secure by entrepreneurs. ${ }^{12}$ In most cases, entrepreneurs end up with bootstrapping techniques ${ }^{13}$ to raise their capital and mitigate their financial manacles by boosting their short-term profits. ${ }^{14}$

The rapid movement of transactions via Internet is indeed a technological advantage. Technological advancement has made crowdfunding exercises viable in the local and global market. ${ }^{15}$ Some entrepreneurs have started to utilise the Internet to seek financial assistance directly from the general public (the "crowd") which may include investors such as business angels ${ }^{16}$, banks or venture capital funds. ${ }^{17}$ Crowdfunding has not only resolved financial issues as to business ventures but also helped fund various social and charitable projects. These included the production of Maria Schneider's jazz album by the fans through reward based crowdfunding, enabling the Little League team to reach a championship tournament, provide funds for the disaster relief of Farrah Soudani ${ }^{18}$ and other projects. The social crowdfunding websites for global fund solicitation that have emerged, such as Globalgiving, First Funder, FundAnything, GoFundMe, GiveForward, have become evidence of the wisdom of the crowd or power of the crowd in helping needy individuals or communities.

\subsection{Crowdfunding defined}

The term "crowdfunding" is derived from the broader concept of "crowdsourcing". It is described as a way to harness the creative solutions for fundraising of a distributed network of individuals. ${ }^{19}$ Thus, the 'crowd' in the crowdfunding exercise is the people connected via the Internet. Lambert \& Schwienbacher (2010) described crowdfunding as:

Crowdfunding involves an open call, essentially through the Internet, for the provision of financial resources either in form of donations 
(without rewards) or in exchange for some form of reward and/or voting rights in order to support initiatives for specific purposes. ${ }^{20}$

Crowdfunding is actually an open call to the worldwide market over the Internet seeking for financial funds or resources in the form of a monetary donation, sometimes in exchange for a future product, service, or reward. ${ }^{21}$

Before computer-mediated crowdfunding, the party seeking funds from the crowd or certain groups of people usually engaged in personal crowdfunding initiatives. For instance, musicians would publicly ask their fans to fund a new album or tour. Fast-growing crowdfunding platforms currently fund a variety of projects, such as fashion, film, product design, and software. ${ }^{22}$

\subsection{Types of crowdfunding}

As stated earlier, primarily, crowdfunding could be categorised into two, firstly community-based crowdfunding, which could either be donation-based or reward-based, and secondly financial return crowdfunding, which could be either P2P lending or equity crowdfunding. The detailed explanation of the community based crowdfunding is as follows:

\section{1) Donation-based crowdfunding:}

Donation is an act of giving away someone's property (donor) without any obligation on the part of the recipient to give anything in return. In the structure of the donation-based crowdfunding, the funders do not expect anything in return for any fund paid to the platform. GlobalGiving was founded in 2002 as a crowdfunding platform collecting donations from the crowd all over the world. The donations received were utilised for charity and social projects. GoFundMe is another example of a donation-based crowdfunding platform. It was launched in 2010 and enabled its users to raise \$120 million in 350 campaigns, from 1.4 million donors. The platform takes 5 percent of each donation and processing fees are imposed on the user on each transaction. Its campaigns had successfully reached the $\$ 1$ billion plateau as of October 2015. One of its recipients was Farrah Soudani who had been critically injured in a movie theatre massacre in the US in November 2012. Her medical expenses were duly paid from the fund raised by this platform. ${ }^{23}$

\section{2) Reward-based crowdfunding}

In contrast to donation-based crowdfunding, the funders of reward-based crowdfunding expect something in return for the fund/donations given to the platform. These rewards could be in the form of acknowledgements, like thankyou mail, an artist's autograph or mentioning the crowdfunder's name on the cover of a film DVD or music CD. In some instances, the funders receive invitations 
to visit a film set or artist workshop or dinner or performance and a token of appreciation, like T-shirts advertising the project or group funded. This type of crowdfunding exercise could be in the form of crowd-sponsoring or crowd preselling $^{24}$ like the successful project of Maria Schneider's jazz album in 2004 which was campaigned via ArtistShare. The funders were allowed to download the album upon release for a $\$ 9.95$ contribution..$^{25}$

Financial return crowdfunding on the other hand could be further described as;

a) Crowd lending/P2P lending: The crowdfunding platforms act as intermediaries for the funders and the borrowers. P2P crowdfunding platforms would be able to generate their revenue by taking a specified percentage of the loan amount (a one-time charge) from the borrower and a loan servicing fee (either a fixed annual fee or a one-time percentage of the loan amount) from investors/funders. The application process is free for borrowers. The funders will receive their income on each loan. ${ }^{26}$

b) Crowd equity/equity crowdfunding: This structure triggers regulatory issues since it could potentially offer complexity in its exercise. Basically, it is an avenue for the investor to participate in equity. The investors would enjoy return from the investment made based on the terms specified in the campaigns. Many jurisdictions have their own laws pertaining to investments. ${ }^{27}$

The emergence of crowdfunding as a new mechanism for investment prompted regulators to take steps to accommodate its existence via different approaches. 
Table I below illustrates examples of selected crowdfunding platforms according to their origin and types of activity.

Table 1: Examples of crowdfunding platform

\begin{tabular}{|c|c|c|c|c|c|}
\hline No & Companies/entities & Year & $\begin{array}{l}\text { Types of } \\
\text { crowdfunding }\end{array}$ & $\begin{array}{l}\text { Medium } \\
\text { of crowd- } \\
\text { sourcing }\end{array}$ & Origin \\
\hline 1 & $\begin{array}{l}\text { Statue of Liberty } \\
\text { (US government) }\end{array}$ & 1885 & Donation & Newspapers (t) & $\begin{array}{l}\text { United } \\
\text { States }\end{array}$ \\
\hline 2 & GlobalGiving & 2002 & Donation & Internet & $\begin{array}{l}\text { United } \\
\text { States }\end{array}$ \\
\hline 3 & DonorsChoose & 2000 & Donation & I (2006) & $\begin{array}{l}\text { United } \\
\text { States }\end{array}$ \\
\hline 4 & ArtistShare & 2003 & Reward & Internet & $\begin{array}{l}\text { United } \\
\text { States }\end{array}$ \\
\hline 5 & $\begin{array}{l}\text { 1)Prosper.com } \\
\text { 2)Kiva.org }\end{array}$ & 2005 & Debt (P2P) & Internet & $\begin{array}{l}\text { United } \\
\text { States }\end{array}$ \\
\hline 6 & Lending Club & 2006 & Debt (P2P) & Internet & $\begin{array}{l}\text { United } \\
\text { States }\end{array}$ \\
\hline 7 & SliceThePie & 2007 & Reward & Internet & $\begin{array}{l}\text { United } \\
\text { States }\end{array}$ \\
\hline 8 & IndieGoGoSpot.us & 2008 & Reward & Internet & $\begin{array}{l}\text { United } \\
\text { States }\end{array}$ \\
\hline 9 & KickStarter & 2009 & Reward & Internet & $\begin{array}{l}\text { United } \\
\text { States }\end{array}$ \\
\hline 10 & $\begin{array}{l}\text { GoFundMe } \\
\text { Funding Circle } \\
\text { RocketHub }\end{array}$ & 2010 & $\begin{array}{l}\text { Donation } \\
\text { Debt (P2P) } \\
\text { Reward }\end{array}$ & Internet & $\begin{array}{l}\text { United } \\
\text { States } \\
\text { United } \\
\text { Kingdom } \\
\text { United } \\
\text { States }\end{array}$ \\
\hline 11 & Micro Ventures & 2011 & Equity & Internet & $\begin{array}{l}\text { United } \\
\text { States }\end{array}$ \\
\hline 12 & CircleUp & 2012 & Equity & Internet & $\begin{array}{l}\text { United } \\
\text { States }\end{array}$ \\
\hline
\end{tabular}




\section{Benefits and Risks Aspects of Crowdfunding}

Research has revealed that crowdfunding overcomes the distance-related economic frictions usually associated with funds solicitation. ${ }^{28}$ Crowdfunding gives freedom ${ }^{29}$ to the funders and the issuers who seek funding via the intermediation played by the crowdfunding platform. ${ }^{30}$ According to Kirby \& Worner (2014), financial return crowdfunding offers the following benefits:

a. Ability to raise funds without the need to give up large parcels of equity interest.

b. Spread risks to the investor.

c. Reduced cost of capital and higher returns to investors.

d. Leading to job creation via projects funded and economic recovery.

Despite its key benefits, crowdfunding is equally exposed to certain risks, for instance, default, platform closure or failure, fraudulent acts of the parties involved, illiquidity (since there is no secondary market available), cyber-attacks and lack of transparency and disclosure. ${ }^{31}$ In general, the following barriers are associated with crowdfunding exercises, namely:

a. Reputation at stake in case of the failure to meet campaign goals or to generate public interest.

b. The lack of intellectual property (IP) protection to the issuer seeking the funds since, when his idea is posted via the platform, it is vulnerable to be copied.

c. Donors' exhaustion.

d. Lack of a proper regulatory framework in many jurisdictions.

e. Lack of due diligence in investment decision processes.

f. Lack of formal approach. ${ }^{32}$

g. Ethnographic study of the crowdfunders found that the work involved is more time consuming and requires a variety of skills, not unlike running an entrepreneurial venture. ${ }^{33}$

\section{Regulatory Regimes for Crowdfunding: General Overview}

\subsection{Financial Return Crowdfunding}

Modern peer-to-peer lending and equity crowdfunding started to grow in the United Kingdom in 2006, spread to the United States in 2007 and took off in China in $2009 .{ }^{34}$ Since numerous securities laws of many jurisdictions emphasize the protection of investors, market and consumers, regulatory regimes have concentrated on the financial return crowdfunding category. Consequently, many countries started to accommodate this fast growing industry by according their regulatory regimes with necessary adjustments. The methods vary from 
one jurisdiction to another according to its categories, either P2P or equity crowdfunding. Some countries, such as Singapore, are still in the consultation phase. According to Kirby and Worner (2014), generally for P2P crowdfunding, the regulatory approaches are as follows:

\section{Exempt or unregulated due to lack of definition}

The countries which do not have P2P lending markets definitely do not need to regulate the industry while some other countries, like Tunisia and UK, have not yet regulated the industry due to a lack of definition of service based on the nature of crowdfunding itself, which was originally meant for micro-financing. The US allows crowdfunding through exemption. However, the exemption is claimed as it does not mesh well with the nature of crowdfunding. This has created uncertainty for the crowdfunding platforms. The crowdfunding campaign by Michael Migliozzi II and Brian William Flatow was advised to shut down in 2011 due to non-registration since the US Securities Act 1933 requires registration. ${ }^{35}$

\section{Regulated as an intermediary}

In certain jurisdictions, $\mathrm{P} 2 \mathrm{P}$ crowdfunding platforms are deemed as intermediaries or brokers. The laws pertaining to the conduct of intermediaries vary from one jurisdiction to another. In most cases registration with the regulator is a must. Regulations, guidelines or practice directions are issued as to how to register and conduct the $\mathrm{P} 2 \mathrm{P}$ crowdfunding platforms. This indicates that the industry is closely monitored by the dedicated regulators or authorities.

\section{Regulated as banking}

Some jurisdictions classify P2P crowdfunding platforms as banks due to the nature of their function as financial intermediaries. Due to that, the requirements imposed by the regulators on the banking and financial institutions will also be applicable to them. Necessary adjustments or exemptions might be considered since P2P crowdfunding platforms are relatively small.

\section{The US model}

The US model requires double compliance from the market players. First is the compliance with the federal requirements, second is the compliance with the respective state authority. Essentially, the $\mathrm{P} 2 \mathrm{P}$ crowdfunding platforms have to register themselves with the US Securities and Exchange Commission (SEC) since they are treated as public companies. All regulations pertaining to loans origination must be complied with.

The second tier compliance is compliance with the state laws. Each state has its own laws and regulations pertaining to the conduct of $\mathrm{P} 2 \mathrm{P}$ crowdfunding. As a result, some states (like Texas) impose a total ban on $\mathrm{P} 2 \mathrm{P}$ crowdfunding, hence 
no P2P platforms could be run in those states. Some states on the other hand allow the practice ( $\mathrm{P} 2 \mathrm{P}$ crowdfunding platforms) but impose certain limitations on the type of investors from who the platforms can solicit funds. California is an example of this type. Malaysia follows the California approach, since the Securities Commission of Malaysia only allows micro-fund platforms to carry on the P2P crowdfunding exercise with limitation on its investors. Only sophisticated and angel investors are allowed to be solicited while retail investors are totally prohibited for the exercise. The US model also requires multiple registration should the platforms wish to operate in multiple states.

\section{Prohibited}

Some countries impose a total ban on the $\mathrm{P} 2 \mathrm{P}$ crowdfunding platforms while some allow with restriction like Malaysia.

\section{Collective Investments Scheme (CIS)}

In addition to the above mentioned approaches, another form of regulatory adjustment is based on the concept of a collective investment scheme (CIS). TrustBuddy International is an example of this approach.

For equity crowdfunding on the other hand, the regulatory approaches are as follows:

1. Total banning of equity crowdfunding.

2. Equity crowdfunding is allowed with either strict barriers as to its entry to the market or with limitations as to the type of issuers, investors and funds' limits. ${ }^{36}$

There is a trend in the development of legal infrastructure for equity crowdfunding. A number of jurisdictions have taken steps to relax some legal requirements imposed on the general securities transactions on the equity crowdfunding exercises. In the United States, for instance, Jumpstart Our Business Startups (JOBS) Act was enacted on 5 April 2012 carving out several exemptions within the existing US securities regulatory framework for equity crowdfunding. ${ }^{37}$ The law was further enhanced by introducing Title III to the JOBS Act on 30 October 2015 aimed at encouraging the growth of the equity crowdfunding market in the US. ${ }^{38}$

Other jurisdictions like Canada, Australia, New Zealand and Italy that are working on regulatory infrastructure for crowdfunding have also adopted a similar approach by introducing exemptions as to the general requirements of the securities. Same goes to Malaysia, which newly issued its Guidelines on Recognised Markets through the Securities Commission of Malaysia ${ }^{39}$ superseding the earlier attempt at regulating the equity crowdfunding made via Regulation of Markets under Section 34 of the Capital Market and Services Act 
2007 (CMSA) ${ }^{40}$ Singapore has also accommodated equity crowdfunding via exemptions granted on its regulated entities. ${ }^{41}$

\subsection{Community-based Crowdfunding}

Currently the laws and regulation for the fund solicitation for donation-based and reward-based crowdfunding is still uncertain. In many jurisdictions, charitable collections by any entities such as trustees or non-profit organisations require registration. California took a proactive step by initiating a direction for the Internet-based crowdfunding based on the definition of a commercial fundraiser. Starting from 1 January 2016, any fundraiser entity that wishes to collect charitable collections from the public must register itself with the state. This is because crowdfunding platforms have been receiving a certain percentage of fees for the charitable funds initiated through their platforms. This enhanced feature of charitable collector via this method is distinguished from the very traditional was of charity collections. The "commercial fundraiser" in California is defined as:

"Any individual, corporation, unincorporated association, or other legal entity who for compensation does any of the following:

1. Solicits funds, assets, or property in this state for charitable purposes

2. As a result of a solicitation of funds, assets, or property in this state for charitable purposes, receives or controls the funds, assets, or property solicited for charitable purposes

3. Employs, procures, or engages any compensated person to solicit, receive, or control funds, assets, or property for charitable purposes

4. Plans, manages, advises, counsels, consults, or prepares material for, or with respect to, the solicitation in this state of funds, assets, or property for charitable purposes, but is disqualified as a fundraising counsel for charitable purposes pursuant to subdivision (a) of California Government Code, Section 12599.1 ${ }^{42}$

Based on the definition of commercial fundraiser, any collection which is either purely charitable in nature or motivated by the prospect of a reward must be registered according to the law. There are other requirements imposed on such registered entities pertaining to disclosure requirements, management and reporting, dissolution of the entity and complaint management. ${ }^{43}$

The approach taken or to be taken by other jurisdictions to regulate community-based crowdfunding might vary from one jurisdiction to another as how regulations on financial return crowdfunding are tackled and drafted. ${ }^{44}$ 


\section{Regulatory regime for Crowdfunding in Malaysia}

\subsection{Equity Crowdfunding in Malaysia}

On $21^{\text {st }}$ August 2014, the Securities Commission issued the Public Consultation Paper No. 2/2014, "Proposed Regulatory Framework for Equity Crowdfunding". As a result of this issuance, Guidelines on Regulation of Markets under Section 34 of the Capital Markets and Services Act 2007 was released on 10 February 2015 to introduce new requirements for the registration of equity crowdfunding (ECF) platforms and provide governance arrangement for the operation of such platforms. It replaced the Guidelines on Regulation of Markets which was issued in September 2007. ${ }^{45}$

A call for registration to become a ECF operator was also released in February 2015. The regulator received 27 applications from the ECF to operate their platforms. The Securities Commission Malaysia eventually announced the approval of six registered equity crowdfunding platforms aimed at giving small businesses and entrepreneurs greater access to capital. The approved platforms are Alix Global, Ata Plus, Crowdonomic, Eureeca, pitchIN and Propellar Crowd+. Eventually, on 11 December 2015, a new guideline was issued viz the Guidelines on Recognised Markets (the Guideline) which came into force on 15 December 2015. ${ }^{46}$

The Guideline provides general provisions on the requirements for registration and its procedure, conduct, and operation of the ECF platforms vide Part F of the Guideline. Generally, the Guideline takes the approach of the US model in regulating its financial return crowdfunding. In essence, it recognises both equity and $\mathrm{P} 2 \mathrm{P}$ lending as methods of eligible crowdfunding exercises. However, it imposes certain limitations on its structure such as limitation on the eligible issuers (fund seekers) as stipulated in Article 12.14 to 12.17, on funds limits and investment limit as mentioned in Article 12.18 and Article 12.22, and on the type of investors for a micro-funding entity as prescribed in Article 12.17 of the Guideline.

Since the provisions in the Guideline are general, it is applicable to both conventional equity and Islamic equity crowdfunding. The only provisions related to Shariah requirements are those stipulations on the appointment of Shariah advisors in Part E of the Guideline. Unlike Singapore, there is no Islamic equity crowdfunding being registered in Malaysia. In Singapore, the rooting of crowd-funding activities, especially equity crowd-funding, has motivated one of the equity crowd-funding platforms to run its activities based on Islamic principles. ${ }^{47}$ Club Ethis, launched in March 2014, a Singapore-based company, has claimed itself as the world's first Shariah compliant crowdfunding platform. It claims to be supervised by two in-house Shariah scholars. Despite lack of 
proper regulation on the Shariah-complaint equity crowdfunding, it continues its mission and has topped $\mathrm{S} \$ 1.3$ million worth of transactions over its platform. ${ }^{48}$ Thus, with the expectation of the potential emergence of Shariah-compliant equity crowdfunding in Malaysia, the current state of laws is lacking proper regulatory and Shariah governance frameworks.

\subsection{Community-based crowdfunding}

Community-based crowdfunding is not alien to the Malaysian community, in particular the Malays. The Khairat system ${ }^{49}$ is a prevailing crowdfunding practice in the Malay communities. The 'Kutu' system, also a community lending arrangement made mutually among its participants is an example of social-based crowdfunding activities. ${ }^{50}$ Charities are unseparated from human beings generally. Before the coming of the Internet or computer mediated charity solicitation, the practice of seeking funds for charities and social causes has been dominant in the Malaysian community. The collections are usually carried out by registered or legal entities while some might be done by illegal persons. Religious charitable collections, especially pertaining to waqf or any other Muslims charities, are governed by the states or by any eligible entity prescribed by the Malaysian Constitution.

Constitutionally, the provision of charitable endowment or charities is provided by Item 1 of the List II (State List) in the Ninth Schedule of the Malaysian Federal Constitution. State List is a list of matters to be dealt with by each state government of the federation independently, without interference of the federal government. Article 74 of the Malaysian Federal Constitution clearly builds a demarcation of the legislative power of the federal government and the state government. The Federal legislature has the power to enact laws for the matters listed in List I (Federal List) of the Ninth Schedule and List III (Concurrent List). The state legislature on the other hand is empowered to make laws in relation to matters listed in List II and List III subject to the restrictions imposed by the Federal Constitution.

However, Article 76 of the Federal Constitution stipulates deliberately the exclusive power granted upon the federal legislature namely the Parliament to make laws for the states. The matters are:

a. Laws made for the purpose of implementing any treaty, agreement or convention between the federation and any other country or any decision of an international organisation of which the federation is a member except in matters relating to Islamic law or Malays customs or in respect to native laws or customs of the people in Sabah and Sarawak which could only be dealt with after consultation of the state government; or 
b. Laws for the purpose of promoting uniformity of the law of the two or more states; or

c. If it is requested by the state legislature

In relation to the power bestowed upon the Parliament in matters spelt out under (b) and (c), such power is exercisable with specified restrictions, viz:

i. Such law shall not be in force unless and until it is adopted by the state legislature as a state law as vividly stated in sub (3) of Article 76 of the Federal Constitution.

ii. Such power shall not be exercised on Sabah and Sarawak in matters related to land and local government as provided by Article 95D of the Federal Constitution.

iii. The consent of the states in West Malaysia need not be consulted in matters related to land and local government as mentioned in sub (4) of Article 76 of the Federal Constitution.

Item 1 of the State List ${ }^{51}$ stipulates that:

1. Except with respect to the Federal Territories of Kuala Lumpur, Labuan and Putrajaya, Islamic law and personal and family law of persons professing the religion of Islam, including the Islamic law relating to succession, testate and intestate, betrothal, marriage, divorce, dower, maintenance, adoption, legitimacy, guardianship, gifts, partitions and non-charitable trusts; Wakafs and the definition and regulation of charitable and religious trusts, the appointment of trustees and the incorporation of persons in respect of Islamic religious and charitable endowments, institutions, trusts, charities and charitable institutions operating wholly within the State; Malay customs; Zakat, Fitrah and Baitulmal or similar Islamic religious revenue; mosques or any Islamic public place of worship, creation and punishment of offences by persons professing the religion of Islam against precepts of that religion, except in regard to matters included in the Federal List; the constitution, organization and procedure of Shariah courts, which shall have jurisdiction only over persons professing the religion of Islam and in respect only of any of the matters included in this paragraph, but shall not have jurisdiction in respect of offences except in so far as conferred by federal law; the control of propagating doctrines and beliefs among persons professing the religion of Islam; the determination of matters of Islamic law and doctrine and Malay custom. 
Thus, Muslims' charities fall within the jurisdiction of the state legislature. This means that each state of the federation of Malaysia, except the Federal Territories of Kuala Lumpur, Labuan and Putrajaya, shall have the right to govern matters envisaged in the State List. This also suggests that each state shall have its own version of laws pertaining to matters under the State List. Thus, Muslims' charities shall be governed by each state's enactment. Each state shall have their own enactment governing the administration of Islamic law. Same goes for Hindu endowments, as stated in Item 15 of the Federal List. ${ }^{52}$

The constitution makes it clear that charities or charitable institutions shall be governed by the federal government, as vividly mentioned in Article 15 of the Federal List. It states:

15. Labour and social security, including -

(a) trade unions; industrial and labour disputes; welfare of labour including housing of labourers by employers; employer's liability and workmen's compensation

(b) unemployment insurance; health insurance; widows', orphans' and old age pensions; maternity benefits; provident and benevolent funds; superannuation; and

(c) charities and charitable institutions; charitable trusts and trustees excluding Wakafs; Hindu endowments

Thus, general charities which collect donations from the crowd irrespective of donors' religions, could be arguably governed under the federal government. Currently, any charitable organisations are subjected to the Trustee Act 1949. The potential rise of Islamic community-based crowdfunding would invite jurisdictional issues between federal and state laws.

\section{Discussion and Conclusion}

The potential of crowdfunding as a fundraising tool for both financial and social causes is undeniable. In Europe, the European Commission has published a guide for small businesses explaining what crowdfunding is and how to use it. ${ }^{53}$ As discussed, the US government had introduced the JOBS Act and necessary exemptions to its securities laws to accommodate its financial return crowdfunding exercises. Other jurisdictions, such as Australia, Singapore, China, Singapore, Malaysia and many more, have taken similar actions especially for the regulation of the financial return.

In respect of the Malaysian regulatory regime, the current position of its regulatory framework seems to only support the emergence of financial return crowdfunding, be it P2P lending or equity crowdfunding. Its current guideline namely, the Guidelines on Recognised Markets (The Guideline) spells out the do's 
and don't's of the registration and general management of the registered entities. Since Malaysia is one of the most important Islamic finance hubs in the world, the demand from the market for Shariah-Compliant equity crowdfunding should be expected. Based on this expectation, the requirements for the appointment and disclosure of the Islamic capital market products vide Part $\mathrm{E}$ of the Guideline is not sufficient in ensuring a proper and holistic Shariah governance framework for crowdfunding activities.

It was suggested that for Shariah-compliant financial return crowdfunding the possible Shariah contracts would be Qard, Murabahah, Ijarah, Salam, Istisna', Bay Al-Dayn, Musharakah, Mudharabah and Wakalah. ${ }^{54}$ Hence, parameters of the Shariah contracts and available structures for Islamic equity crowdfunding should be provided by the regulator. Furthermore, the Guideline should specify the criteria for the eligible parties in the Shariah equity crowdfunding exercises. In addition, the present position on the requirement of the appointment of the approved Shariah advisor could lead to market to uncertainty and possibly dispute as to the approved transactions in the absence of solid Shariah parameters pertaining to such crowdfunding activities.

As far as the community-based crowdfunding in Malaysia is concerned, be it donation-based or reward-based, there is no proper legal framework available to the market players. The applicable laws for charitable institutions which solicit donations from the general public is the Trustee Act 1949. The provisions of the Trustee Act 1949 would be insufficient to cater for the new structure of community-based crowdfunding since it employs an intermediary role for the crowdfunding platforms which bring in the funders and the fund seekers. Such an intermediary aspect comes with certain percentage of fees which is not found in the traditional way of donation solicitation. This attribute makes the two different from each other.

Another aspect of legal concern for community-based crowdfunding is the jurisdictional issue between federal and state governments when the communitybased crowdfunding seeks to run its operation based on the Shariah principles. It is a trite law that both jurisdictions are constitutionally provided. One should not encroach the other's jurisdiction unless specifically permitted by the constitution. Islamic laws are within the ambit of each state's jurisdiction. It was proposed that Hibah and Sale are two suitable Shariah contracts that could be employed in Islamic community-based crowdfunding. ${ }^{55}$ Should any community-based crowdfunding exercise opt to operate in accordance with the Shariah principles, a proper parameter and Shariah governance framework would therefore become necessary.

It is a well noted fact that the very intention of resorting to crowdfunding methods is to seek funds from the Internet-connected crowd. The crowd over 
the Internet are multi-religious. It is therefore inferred based on the nature of transactions, that the persons involved in the crowdfunding exercises are not necessarily Muslims. Should the transactions be founded in Malaysia, or the targeted crowd be Malaysian, the donations or charities solicited would fall within the purview of federal laws, hence Trustee Act 1949 will be applicable. As at present, there is no sufficient legal infrastructure to cater for the new model of donation solicitation through crowdfunding.

In addition, since crowdfunding, either financial return or community-based, usually involves cross-border transactions, dispute settlement mechanisms should also be looked into, particularly when the structure employs Islamic principles. This is because Islamic law is inapplicable in many jurisdictions.

Therefore, it is recommended as follows:

- The provisions of the Guidelines on Recognised Markets are to be revisited and additional adjustments should be incorporated to strengthen the Shariah governance aspects of the Islamic equity crowdfunding in the country. This is pertinent since Shariah-compliant transactions run based on the nature of the Shariah contracts involved

- Shariah parameters should be issued by the regulators to allow crowdfunding activities to be run on the basis of Shariah principles

- A new definition of 'commercial fundraiser' as administered in California, USA, for instance is be crafted and included in the current legal framework pertaining to charitable organisations. A proper regulation is highly needed to ensure that proper governance of the public fund or trust funds can materialise. The existence of a similar intermediary role of the platform in the community-based crowdfunding exercise would make the structure more complex and require an additional legal framework to protect the parties involved, particularly the funds, beneficiaries and the donors

- It is strongly suggested that alternative dispute resolutions (ADR) should be employed as a term of the transactions to govern disputes between the parties involved to avoid jurisdictional issues arising from any court proceedings. The award of arbitration, for instance, is enforceable in various jurisdictions

Indeed, crowdfunding is an infant industry that grows fast in parallel with the technological advancement that the world presently experiences. Due to that, necessary adjustments should be expeditiously made to ensure that its operation is properly supervised and the parties involved are well-protected. 


\section{Notes:}

* Apnizan Abdullah holds the LL.B (Honours) and Master of Comparative Laws (MCL) from the International Islamic University Malaysia (IIUM) obtained in 2003 and 2004 respectively. Prior to joining IAIS, she was a lecturer at the Universiti Tunku Abdul Rahman (UTAR) and the University of Malaya. She was also a researcher at the International Shariah Research Academy for Islamic Finance (ISRA). She obtained her Chartered Islamic Finance Professional certificate (CIFP) from the International Centre for Education in Islamic Finance (INCEIF) in 2011 and her LL.B (Shariah) from the IIUM in 2014. She currently serves the International Institute of Advanced Islamic Studies (IAIS) Malaysia as a Research Fellow. She can be contacted at apnizan@iais.org.my.

1. "The Statue of Liberty and America's crowdfunding pioneer", BBC News, $<\mathrm{http}$ :// www.bbc.com/news/magazine-21932675> (accessed 25 December 2015).

2. Joachim Hemer, "A Snapshot On Crowdfunding", Working papers firms and region, No. R2/2011,(2011):1-2, <http://hdl.handle.net/10419/52302> (accessed 25 December 2015).

3. Liau, Y-Sing, "Islamic Crowdfunding Takes Root in Asia in Boon to Entrepreneurs", Bloomberg Business, <http://www.bloomberg.com/news/ articles/2015-11-08/islamic-crowdfunding-takes-root-in-asia-in-boon-toentrepreneurs $>$ (accessed 25 December 2015)

4. Hemer, 4-6.

5. Money provided by investors to start-up firms and small businesses with perceived long-term growth potential. This is a very important source of funding for start-ups that do not have access to capital markets. It typically entails high risk for the investor, but it has the potential for above-average returns. Most venture capital comes from a group of wealthy investors, investment banks and other financial institutions that pool such investments or partnerships. This form of raising capital is popular among new companies or ventures with a limited operating history, which cannot raise funds by issuing debt. The downside for entrepreneurs is that venture capitalists usually get a say in company decisions, in addition to a portion of the equity. For further reading, refer, <http://www. investopedia.com/terms/a/angelinvestor.asp $>$ (accessed on 10 January 2016).

6. The capital or financial backing for small start-ups or entrepreneurs provided by investors are usually found among an entrepreneur's family and friends. The capital they provide can be a one-time injection of seed money or ongoing support to carry the company through difficult times. Angel investors give more favorable terms than other lenders, as they are usually investing in the person rather than the viability of the business. They are focused on helping the business succeed, rather than reaping a huge profit from their investment. For further reading, refer, n.5.

7. Hemer, n.4 at 4-5.

8. <http://oag.ca.gov/charities/forms\#fundraisers> (accessed on 10 January 2016).

9. <http://www.nonprofitlawblog.com/category/fundraising/> (accessed 10 January 2016)

10. C. Steven Bradford, "Crowdfunding and The Federal Securities Laws", Columbia Business Law Review, Vol. 1 (2012):1-150, at 5; Armin Schwienbacher \& 
Benjamin Larralde, "Crowdfunding of Small Entrepreneurial Ventures", (2010): 1494-1533, at 3, < http://ssrn.com/abstract $=1699183>$ ( accessed 28 December 2015); CASI, "Crowdfunding in Sustainable Innovation", CASI Policy Brief, (June, 2015): 1-2, <http://www.casi2020.eu/app/web1/files/download/casipb-6-2015.pdf $>$ (accessed 25 December 2015); Venkat Kuppuswamy \& Barry L. Bayus, "Crowdfunding Creative Ideas: The Dynamics Of Project Backers In Kickstarter", (2015): 1, <http://ssrn.com/abstract=2234765> (accessed 25 December 2015); Hemer, 2.

11. Andy Cosh, Douglas J. Cumming \& Alan Hughes, "Outside Entrepreneurial Capital", Economic Journal, 119 (2009): 2-4; See also Schwienbacher \& Larralde, 1-2.

12. Bradford, 1-2.

13. A situation when an entrepreneur starts a company with little capital by obtaining personal finances or from the operating revenues of the new company. Bootstrapping may not provide enough investment for the company to become successful at a reasonable rate. For further reading, refer, <http://www. investopedia.com/terms/a/angelinvestor.asp > (accessed on 10 January 2016).

14. For further details, see Amar Bhide, "Bootstrap Finance: The Art of Start-up", Harvard Business Review, Vol. 70, No. 66 (1992): 109-117; Joakim Winborg \& Hans Landstrom, "Financial Bootstrapping in Small Businesses: Examining Small Business Managers'Resource Acquisition Behaviours", Journal of Business Venturing, Vol. 16 (2001): 235-254; Jay Ebban \& Alec Johnson, "Bootstraping in Small firms: An Empirical Analysis of Change Over Time", Journal of Business Venturing, Vol. 21 (2006): 851-865.

15. Eleanor Kirby \& Shane Worner, "Crowdfunding: An Infant Industry Growing Fast", Staff Working Paper of the IOSCO Department, SWP3/2014 (2014):10, $<$ http://www.iosco.org/research/pdf/swp/Crowdfunding-An-Infant-IndustryGrowing-Fast.pdf $>$ (accessed 28 December 2015).

16. Angel investors. See n.6.

17. Schwienbacher \& Larralde, 1-2; Elizabeth M. Geber, Julie S. Hui \& Pei-Yi Kuo, "Crowdfunding: Why PeopleMotivated to Post and Fund Projects on Crowdfunding Platforms", (2012): 1, http://www.juliehui.org/wp-content/ uploads/2013/04/CSCW_Crowdfunding_Final.pdf (accessed 26 December 2015).

18. Freedman, David M and Nutting, Mathew R, "A brief of Crowdfunding: Including Rewards, Donations, Debt and Equity Platforms in the USA", (2015):5, <http:// www.freedman-chicago.com/ec4i/History-of-Crowdfunding.pdf $>$ (accessed on 25 December 2015)

19. Geber, Hui \& Kuo, 2.

20. For further reading, See, Lambert, $\mathrm{T}$ and Schwienbacher, A, "An Empirical Analysis of Crowdfunding" <http://ssrn.com/abstract $=1578175>$ (accessed on 25 December 2015).

21. Hemer, 8.

22. Geber, Hui \& Kuo, 1-2.

23. Freedman \& Nutting, 5.

24. Hemer, 13-14.

25. Freedman \& Nutting, 1. 
26. Ibid., 3 .

27. CASI Policy Brief is prepared by the Common Framework for Assessment and Management of Sustainable Innovation (CASI) under the project title "Public Participation in Developing a Common Framework for Assessment and Management of Sustainable Innovation (CASI)". The CASI consortium consists of 19 partners representing 12 European countries. The project is funded under the $7^{\text {th }}$ Framework Programme of the European Community, SCIENCE-INSOCIETY-2013.1.2. See, CASI, "Crowdfunding in sustainable innovation", CASI Policy Brief, CASI-PB-6.2015 (June, 2015):2, <http://www.casi2020.eu/ app/web1/files/download/casi-pb-6-2015.pdf $>$ (accessed 25 December 2015).

28. Ajay K. Agrawal, Christian Catalini \& Avi Goldfarb, "The Geography Of Crowdfunding”, Working Paper 16820 (February, 2011):1-2, <http://www. nber.org/papers/w16820http://www.nber.org/papers/w16820> (accessed 25 December 2015); See also, Hui, Gerber \& Greenberg, "Easy Money? Demands of crowdfunding works", (2012), Technical Report No 4.

29. CASI, 5.

30. Ajay K. Agrawal, Christian Catalini \& Avi Goldfarb, "The Geography Of Crowdfunding...", 1-2.

31. Kirby \& Worner, 4-5.

32. CASI, 2.

33. Julie Hui, Elizabeth Gerber \& Mike Greenberg, "Easy Money? The Demands of Crowdfunding Work", Technical Report 4, (2012):2.

34. Kirby \& Worner, 12.

35. Bradford, 6.

36. For example Article 12.14 to 12.19 of Guidelines on Recognised Markets, Securities Commission Malaysia stipulates prohibited list of issuers of the ECF platforms.

37. Hu Ying, "Regulation of Equity Crowdfunding in Singapore", (March, 2015): 2, <http://law.nus.edu.sg/cbfl/pdfs/working_papers/CBFL-WP-HY01.pdf $>$ (accessed on 25 December 2015).

38. Freedman, 7.

39. Issued on December 11, 2015

40. Previously issued on February 10, 2015.

41. For further reading, See, Hu Ying, "Regulation of Equity Crowdfunding in Singapore", (March, 2015): 2, <http://law.nus.edu.sg/cbfl/pdfs/working_papers/ CBFL-WP-HY01.pdf $>$ (accessed on 25 December 2015.

42. <http://oag.ca.gov/charities/forms\#fundraisers $>$.

43. Ibid.

44. Kirby \& Worner, 5.

45. <http://www.sc.com.my/post_archive/sc-releases-new-guidelines-to-facilitateequity-crowdfunding/>(accessed on 25 December 2015).

46. Ibid.

47. Islamic crowd-funding refers to the crowd-funding activities which are Shariahcompliant.

48. CrowdFund insider, "Shari'ah Compliant Crowdfunding Platform Grows in Singapore \& Indonesia", <http://www.crowdfundinsider.com/2015/01/61654Shariah-compliant-crowdfunding-platform-grows-in-singapore-indonesia/> 
(accessed 25 December 2015).

49. Collections made by mutual arrangement in a community for certain benefits such as payment of funeral expenses or natural disaster or any cause agreed between its participants.

50. The Kutu system, variously known as kootus, cheetus, chit funds, hweis, or tontines etc, is prohibited by law. Section 2 of Kootu Funds (Prohibition) Act 1971 defines "kootu fund" as a scheme or arrangement variously known as a kootu, cheetu, chit fund, hwei, tontine or otherwise whereby the participants subscribe periodically or otherwise to a common fund and such common fund is put up for sale or payment to participants by auction, tender, bid, ballot or otherwise and includes any scheme or arrangement which, with variations, partakes of the nature of a kootu, cheetu, chit fund, hwei or tontine.

51. Ninth Schedule of the Malaysian Federal Constitution

52. Ibid.

53. CASI, 6.

54. Aznan Hasan, "Pelaburan Secara Crowdfunding dan Isu-isu Syariah Yang Berkaitan", paper presented at Muzakarah Penasihat Syariah Kewangan Islam 2015 Kali ke-10 at $12^{\text {th }}$ Kuala Lumpur Islamic Finance Forum 2015 held at Royal Chulan Kuala Lumpur, 3 December 2015, (2015):, 8-9.

55. Ibid, 8 .

\section{References}

Agrawal, A.K., Catalini, C. \& Goldfarb, A. (February, 2011). The Geography Of Crowd-funding, Working Paper 16820. Retrieved December 25, 2015. http://www. nber.org/papers/w16820http://www.nber.org/papers/w16820.

Agrawal, A.K., Catalini, C. \& Goldfarb, A. (June, 2013): "Some Simple Economics Of Crowd-funding", Working Paper 19133. Retrieved December 25, 2015. http:// www.nber.org/papers/w19133.

BBC News (n.d). "The Statue of Liberty and America's crowdfunding pioneer", Retrieved December 25, 2015. http://www.bbc.com/news/magazine-21932675.

Bhide, A. (1992). "Bootstrap Finance: The Art of Start-up", Harvard Business Review, Vol. 70, No. 66, pp. 109-117.

Bradford, C. S. (2012). "Crowd-funding and The Federal Securities Laws", Columbia Business Law Review, Vol. 1, pp. 1-150.

Cosh, A., Cumming, D.J. \& Hughes, A, (2009) "Outside Entrepreneurial Capital", Economic Journal, Vol. 119, pp. 1494-1533.

CrowdFund Insider. (2015) "Shari'ah Compliant Crowdfunding Platform Grows in Singapore \& Indonesia", Retrieved December 25, 2015. http://www. crowdfundinsider.com/2015/01/61654-Shariah-compliant-crowdfunding-platformgrows-in-singapore-indonesia/. 
Ebban, J. \& Johnson, A. (2006). "Bootstraping in Small firms: An Empirical Analysis of Change Over Time”, Journal of Business Venturing, Vol. 21, pp.851-865.

Eleanor Kirby \& Shane Worner, (2014). “Crowd-Funding: An Infant Industry Growing Fast”, Staff Working Paper of the IOSCO Department, SWP3/2014 10. Retrived December 28 2015. http://www.iosco.org/research/pdf/swp/Crowd-funding-AnInfant-Industry-Growing-Fast.pdf .

Freedman, David M and Nutting, Mathew R. (2015). "A brief of Crowdfunding: Including Rewards, Donations, Debt and Equity Platforms in the USA". Retrieved December 25, 2015. http://www.freedman-chicago.com/ec4i/History-ofCrowdfunding.pdf.

Geber, E.M., Julie S. Hui, J.S. \& Kuo, P. (2012). "Crowdfunding: Why People Motivated to Post and Fund Projects on Crowdfunding Platforms". Retrieved December 26, 2015. http://www.juliehui.org/wp-content/uploads/2013/04/CSCW Crowdfunding_Final.pdf.

Hasan, A. (December, 2015). Pelaburan Secara Crowdfunding dan Isu-isu Syariah Yang Berkaitan. Paper presented at Muzakarah Penasihat Syariah Kewangan Islam 2015 Kali ke-10 at $12^{\text {th }}$ Kuala Lumpur Islamic Finance Forum 2015 held at Royal Chulan Kuala Lumpur, 3 December 2015.

Hemer, J. (2011). A Snapshot on Crowd-funding, Working papers firms and region, No. R2/2011. Available online at http://hdl.handle.net/10419/52302.

Hui, J., Gerber, E. \& Greenberg, M. (2012). Easy Money? Demands of crowdfunding works. Technical Report No 4.pp.1-11.

$\mathrm{Hu}$ Ying, H. (March, 2015). "Regulation of Equity Crowdfunding in Singapore". Retrieved December 25, 2015. http://law.nus.edu.sg/cbfl/pdfs/working_papers/ CBFL-WP-HY01.pdf.

Lambert, T and Schwienbacher, A. (2010). “An Empirical Analysis of Crowdfunding”. Retrieved December 25, 2015. http://ssrn.com/abstract=1578175.

Liau, Y-Sing.(November, 2015). "Islamic Crowdfunding Takes Root in Asia in Boon to Entrepreneurs", Bloomberg Business. Retrieved December 25, 2015. http://www. bloomberg.com/news/articles/2015-11-08/islamic-crowdfunding-takes-root-in-asiain-boon-to-entrepreneurs.

Mah Weng Kwai (2015). "Equity Crowd Funding in m,alaysia As An Alternative Fund Raising Mechanism”. Retrieved December 25, 2015. http://www.mahwengkwai. com/equity-crowd-funding-in-malaysia-an-alternative-fund-raising-mechanism/.

Kuppuswamy, V. and Bayus, B. L. (November 2, 2015). "Crowd-funding Creative Ideas: The Dynamics of Project Backers in Kickstarter", UNC Kenan-Flagler Research Paper No. 2013-15. Retrieved December 25, 2015. http://ssrn.com/ abstract=2234765 or http://dx.doi.org/10.2139/ssrn.2234765.

Schwienbacher, A. and Larralde, B. (September 28, 2010). "Crowd-funding of Small Entrepreneurial Ventures". Retrived December 28, 2015. http://ssrn.com/ abstract=1699183 or http://dx.doi.org/10.2139/ssrn.1699183. 
The Association of Chartered Certified Accountants. (October, 2014). "Global SME Performance Review". Retrieved December 25, 2015. http://www.accaglobal.com/ content/dam/acca/global/PDF-technical/small-business/pol-tp-bitg.pdf.

Winborg, J. \& Landstrom, H. (2001). "Financial Bootstrapping in Small Businesses: Examining Small Business Managers' Resource Acquisition Behaviours", Journal of Business Venturing, Vol. 16, pp.235-254. 